\title{
Determinants Of Stock Option Use By Chinese Companies
}

\author{
Lei Luo, Ph.D., Xi'an Jiaotong University, P.R. China
}

\begin{abstract}
Using a sample of 225 stock option grants over the period January 2006 to June 2013, we examine the economic determinants of stock option use in Chinese firms from the optimal contract and managerial power approaches. We investigate whether the same economic factors can explain stock option awards to different types of target grantees (including directors and senior executives, technical and business personnel, and special talents introduced in the future). In consistent with the optimal contract theory, we find that the scope of stock option plans is negatively associated with firm size, dividend dummy, and three ownership measures (managerial ownership, blockholder ownership, and foreign ownership). Furthermore, we find that the scope of stock option plans is positively related to book-to-market ratio and prior stock returns, but the coefficients are significant only when the stock options awards cover senior managers. We also find that the impact of risk is different when options are targeted to different types of employees. In consistent with the managerial power theory, we find that the scope of stock option plans is inversely related to state ownership. As for the other economic factors, their degree of impact is found to be different across a broad base of employees. In general, ownership variables are more relevant to key technical and business personnel, while firm characteristics variables are more relevant to top management.
\end{abstract}

Keywords: Stock Options; Incentives; Optimal Contract; Black-Scholes Value; China

\section{INTRODUCTION}

ince 1990s, stock options have become popular compensation methods and have received considerable attention in the literature (e.g., Yermack, 1995; Core and Guay, 1999; Murphy, 1999). Stock options are used as long term incentive compensation to align the interests of mangers and shareholders. However, sometimes in practice entrenched managers use stock option plans as a device to transfer excessive benefits to themselves.

Although stock options have been used extensively in western countries, they become a relatively new form of managerial compensation in China since 2006. The Chinese market presents a unique case in the study of the economic determinants of stock options, because the institutional context in China is very different from that of more developed western countries. First, China's legal protection and corporate governance are weaker than those of developed countries. Second, the State often retains substantial ownership, which is undertaken by diff erent types of agencies. Third, Chinese stock option plans have many special characteristics. While stock options represent a large component of executive compensation in U.S. companies, their share in total compensation is much lower in Chinese companies. Moreover, most of the Chinese stock option plans (96\% for our data) cover both executives and non-executive employees. Interestingly, Chinese firms are more likely to launch stock option plans during bear markets. In general, the Employee Stock Option (ESO) regulations in China are even stricter than those in developed economies. For example, the lower bound of the exercise price is set by law. More importantly, option plans are required to be performance-vested. In China, since stock options are required to be expensed, they are used less in poorly performing firms.

Given the specific institutional background, the use of Chinese data allows us to test whether Western-style managerial incentive compensation is compatible with Chinese unique managerial labor market. To the best of our 
knowledge, Li and Liu (2010), Yu (2011) and Lv et al. (2011) are the only studies to examine the factors that induce Chinese companies to adopt stock options. All of these three studies are based on logit regressions with the binary choice on option as the dependent variable. We intend to complement and extend prior literation in several ways. First, we introduce the relative size and value of the stock options grants to provide comprehensive quantitative information on important features of stock option programs. Second, taking into consideration of different motivations for diversified target grantees, we explore the determinants for senior executives, middle level employees and reserved shares, respectively. Third, unlike extant Chinese stock options studies whose sample includes all the firms that announced their stock option incentive plans, our sample includes exclusively firms in the stage of plan implementation. In fact, some draft plans fail to obtain government/shareholder approval and some plans are canceled. In brief, this paper uses detailed Chinese stock option plans data to examine two research questions: (1) To what extent are stock option grants in Chinese listed firms driven by the same economic factors found in western counties? (2) Do the same economic factors explain stock option awards to different target grantees?

The remainder of the paper is organized as follows. Section 2 provides background information on Chinese stock option plans. Section 3 reviews the relevant literature and discusses the formulation of the various hypotheses. Section 4 describes the sample and research model used, and Section 5 presents the analyses and results. Section 6 concludes the paper.

\section{CHINESE STOCK OPTION PLANS}

Chinese law historically prohibited firms from granting stock options for two reasons. First, firms were not allowed to repurchase their shares to grant to their employees. Second, top management were not allowed to transfer their shares during their term of office. In 2005, the launch of the reform of non-tradable shares of listed companies and the amendment of the Company Law of the People's Republic of China eliminated abovementioned source and trading barriers for the shares concerned.

The Measures for the Administration of Equity Incentives of Listed Companies (Trial) (the "Measures") promulgated by the China Securities Regulatory Commission (the "CSRC") became effective on January 1, 2006. The Measures systematically provide for the first time detailed guidelines for the implementation of stock option and stock-based incentive schemes for employees in listed company. Since then, Chinese listed companies that have completed the share-trading reform are allowed to use option-based compensation for top management and employees. Meanwhile, specific regulations are promulgated for state-owned companies to impose stricter requirements in terms of the granting firms' qualifications, size of the stock, recipient eligibility, and exercise criteria ${ }^{1}$. However, several companies attempt to use stock options as a welfare system. For example, some companies set option strike prices significantly lower than their prevailing market price; exercise standards are extremely lax for some option plans; some companies introduce incentive plans immediately prior to positive corporate information disclosure. In order to prevent managers from reaping improper gains from misusing option plans and to restore the intended purpose of stock incentive plans, the CSRC tightened the regulation by promulgating the Memorandums No.1, No.2 and No.3 on Issues Concerning Equity Incentives in 2008. By the end of 2008, the basic framework of equity incentives has been established.

In general, the Employee Stock Option (ESO) regulations in China are even stricter than those in U.S. and other developed economies. Specifically, eligible recipients may include directors, senior executives ${ }^{2}$, core technical personnel and management backbones but exclude supervisors, independent directors. Besides, shareholders with more than $5 \%$ of ownership or actual controllers shall not become target grantees. The size of the option pool shall not exceed $10 \%$ of the company's total share capital and a single grantee cannot hold more than $1 \%$ of the total share capital of the company. In particular, for a senior manager of state-owned enterprises, the prospective equity incentive earnings shall be controlled within $30 \%$ of her total compensation (including the prospective option and equity earnings) during the validity period of an equity incentive plan. The validity period for exercising options shall not exceed 10 years, and the vesting period shall not be less than one year. The exercise price shall not be lower than the higher of the following prices: (1) the closing price of the underlying stock on the trading day immediately prior to the publication of the ESO abstract; and (2) the average closing price of the underlying stock within 30 trading days prior to the publication of the ESO abstract. More importantly, Chinese ESOs should be 
performance-vested. Memorandum No. 1 recommends using both market-based and sector-adjusted performance indicators. Options become vested only when performance is better than previous record. For example, net profits are positive and higher than the latest three-year average before the grant date.

China's accounting standards require companies to recognize the fair value of ESOs expenses in their income statements but do not specify whether such expenses are tax-deductible or not for the firm. Option recipients are subject to income tax upon exercise under Chinese tax law. The taxable income is calculated as the difference between the market price and the exercise price at the time of exercise. Such income is allowed to be apportioned over a period of up to a maximum of twelve months. No tax is carried at the grant date.

\section{LITERATURE REVIEW AND HYPOTHESES DEVELOPMENT}

Studies on incentive compensation plans can mainly be based on the optimal contract approach (OCA) and the managerial power approach (MPA). Under the first approach, incentive compensation plan is designed optimally to reduce agency problems by aligning managers' interests with those of shareholders, whereas under the managerial power approach, executive compensation is not optimal but as a result of managerial power and rent extraction.

\section{The Scope of Stock Option Plans}

\section{Ownership Structure}

According to Jensen and Meckling (1976), managerial ownership ties the interests of managers to those of stockholders, and thus reduces managers' suboptimal actions to harm shareholders. When managers' ownership is large, the demand for stock option awards as an incentive device is likely to be low, because a substitution effect may exist between stock ownership and stock option compensation. In supporting the substitution effect, Mehran (1995) and Ryan and Wiggins (2001) find a negative association between managerial ownership and the attribution of stock options. Contrasting with the optimal contract hypothesis, the managerial power hypothesis suggests a positive relationship between managerial ownership and stock options awards. When managers hold a large proportion of a firm's equity, they become entrenched and may require excessive compensation. Consistent with the MPA, Alves (2011) and Uchida (2006) find a positive relationship between managerial ownership and the attribution of stock options. Interestingly, the results of Chourou et al. (2008) show a negative sign when stock option incentive intensity is used as the dependent variable but a positive sign when tock option mix is used as the dependent variable.

Based on OCA, effective monitoring weakens the need for incentive alignment. We use blockholder (nonstate) ownership, institutional ownership and foreign ownership as proxies for monitoring from shareholders. We expect theses ownership variables to be negatively related to stock option awards. First, larger shareholders have greater incentive and power to influence the actions of managers (Demsetz and Lehn, 1985; Ittner et al., 2003). Second, institutional and foreign shareholders can be viewed as more professional investors. Professional shareholders are expected to have effective monitoring of the management, reducing the need of granting managers stock option incentives. MPA also suggests a negative association between block/institutional/foreign ownership and the scope of stock option plans, because stronger shareholder monitoring alleviates managerial rent extraction problem. In line with theory, many empirical studies document a negative relation between equity-based compensation and block shareholdings (e.g. Chourou et al., 2008; Ittner et al., 2003; Liljeblom et al., 2011; Mehran, 1995; Ryan and Wiggins, 2001).

In China, strong government intervention is a distinct characteristic of firms' ownership structure. In stateowned firms, state owners serve as the government's agents to manage and monitor the firms through a long principal-agent chain. In this situation, the information asymmetry is likely to be large and monitoring to be ineffective. Managers in state-controlled firms might pursue political or multiple objectives, such as employment growth, rather than profit maximization. In state-owned firms, senior managers' compensation is more likely to be related to the civil service pay scale rather than pay-for-performance. Moreover, the regulatory of equity incentives for state holding listed companies is stricter than for other companies. Among the state-controlled firms that have completed the share-trading reform, it is expected about 50-60\% meet the requirement of the State-owned Assets 
Supervision and Administration Commission of the State Council (SASAC) but only around 30\% can obtain approval. Hence, we expect a negative relation between state ownership and stock option awards. Empirically, Cao et al. (2011) and Firth et al. (2006) both report significant pay-performance sensitivities for firms controlled by private blockholders or SOEs rather than those controlled by state agencies. Among others, Chen et al. (2009) point out that firms controlled by state owned enterprises (SOEs) perform better than those controlled by state assets management bureaus (SAMBs) due to better risk bearing and benefit sharing mechanisms, more competitive managers, better monitoring, and less political intervention. Therefore, based on ultimate controlling shareholders' type, we further divide state-controlled firms into SAMBs and SOEs to investigate the impact of different forms of state ownership on stock option choices.

\section{Monitoring Difficulty}

According to Demsetz and Lehn (1985), when operating environment is complex and executive monitoring is difficult, equity-based compensation is demanded to motive mangers to take value-maximizing actions. Based on OCA, we expect monitoring cost proxies, such as firm size, asset complexity, growth opportunities, firm risk, and business segmentations are all positively related to stock option incentives.

Jensen and Meckling (1976) argue that large firms have more complex assets and more difficult to monitor, suggesting more incentives for large firms. Alves, (2011), Chourou et al. (2008), Core and Guay (1999) and Gaver and Gaver (1993; 1995), among others, document a positive relationship between stock option incentives and firm size. On the contrary, Ryan and Wiggins (2001) infer that firm size may negatively affect stock option usage because large firms receive more analysts' coverage and thus have less information asymmetry and lower monitoring costs. However Baker and Hall (2004) and Liljeblom et al. (2011) explain the negative relation as a result of CEO productivity rising at a decreasing rate with firm size. The findings of Liljeblom et al. (2011) and Oyer and Schaefer (2005) support this negative relationship.

In general, firms with more intangible assets and/or with more business segments may experience executive monitoring difficulties, and thereby reduce shareholder value. Based on OCA, we expect firms with high degree of monitoring difficulties are more likely to use of stock options to reduce monitoring costs. Liljeblom et al. (2011) use Capital-to-sales ratio and Firm focus as inverse proxies for monitoring complexity and report a significantly negative relation between Capital-to-sales ratio and the scope of stock option plan.

As suggested by Gaver and Gaver $(1993 ; 1995)$, firms with high growth opportunities suffer from a large information asymmetry between managers and shareholders and thus face greater monitoring costs. Therefore, such firms should offer more incentive compensation to align the interests of managers and shareholders. Many previous studies lend support to a positive association between growth opportunities and stock option incentives (e.g., Gaver and Gaver, 1993; Kato et al., 2005; Ryan and Wiggins, 2001). We use book-to-market ratio (BTOM) as an inverse measure of growth opportunities.

On one hand, risky firms are likely to face greater monitoring difficulty and thus are more likely to motive mangers to take value-maximizing actions with stock options. On the other hand, risky firms tend to lower the contingent compensation because risk-averse managers require higher levels of compensation for assuming the risk. The empirical findings are mixed. While Nagaoka (2005) and Oyer and Schaefer (2005) find a positive correlation between risk and option compensation, Alves (2011) finds the opposite.

\section{Financial Constraints}

Financial constraints can be grouped into short run and long run. In the short run, companies facing liquidity constraints may use stock options as a substitute for cash compensation, because stock options require no cash outlay (e.g., Yermack, 1995; Core and Guay, 2001). Alves (2011), Core and Guay (2001), Nagaoka (2005) and Yermack (1995) document a positive relationship between stock-based compensation and liquidity constraints. However, Ittner et al. (2003) and Uchida (2006) report a negative relationship. This may be explained as liquidityconstrained firms might have less free cash flow problems for unproductive investments. 
In the long run, financial leverage can mitigate agency conflicts between shareholders and managers but induce agency conflicts between debtholders and shareholder. Jensen (1993) argues that debt serves as a control mechanism which reduces management discretion. This suggests that highly leveraged firms have lower needs for equity-based incentives as a control mechanism. John and John (1993) argues that in highly leveraged firms, when managers' interests are aligned with shareholders via equity-based incentives, they tend to choose riskier investments to the detriment of debtholders. And then debtholders require a premium for this potential increase in firm risk. As a result, John and John (1993) predicts that in order to mitigate agency conflicts between debtholders and shareholders, stock-based awards should be negatively related to firms' financial leverage. Empirically, Bryan et al. (2000), Chourou et al. (2008), Ittner et al. (2003), Kato et al. (2005), Ryan and Wiggins (2001) and Uchida (2006) report a negative association between stock options and leverage. In contrast, Choe (2003) develops a model in which stock option awards increase in leverage. He argues that higher leverage reduces the value of stock options by raising the effective exercise price of options, making risky projects less desirable to mangers. To reduce underinvestment problem, more options can be granted to make managers more risk tolerant. Moreover, high financial leverage can indicate a shortage of cash, suggesting a greater use of stock options to save cash. In this sense, Alves (2011) documents a positive relationship between stock options and leverage.

\section{Firm Performance}

Prior studies provide conflicting hypotheses regarding the relation between the scope of stock option plans and firm performance. One hypothesis suggests a positive relationship between stock options and firm performance when stock options are used to reward past behavior (e.g. Core and Guay, 2001; Ittner et al., 2003). An alternative hypothesis suggests a negative relationship between stock options and firm performance as poorly performing firms want to grant more stock options to enforce incentive alignment (Liljeblom et al., 2011). When firms choose incentives, they will take opportunity costs into consideration. In China, stock options are required to be expensed. Expensing stock option incentives may lead to profit-reduction even huge losses. As Chinese firms facing the pressure of delisting if they record three consecutive years of losses, poorly performing firms are less willing to use stock option incentives to avoid profit deterioration. Therefore, we expect a positive relationship between firm performance and stock options.

\section{Prior Plan and Broad-based Plan}

Following Liljeblom et al. (2011), we also examine the effects of prior plan and broad-based plan. We expect less stock option incentives if a prior plan is in effect. If a stock option plan is targeted to both top management and non-executive employees, we call it a broad-based plan and expect it to be large.

\section{Research on Stock Options in China}

Although stock options have been used extensively in western countries, only recently have they become a component of managerial compensation in China. Limited empirical research has been conducted to examine the determinants of stock option use by Chinese companies. Li and Sanséau (2013) choose 127 Chinese listed companies adopting option-based compensation plans as their sample to examine the influential factors of equitybased pay. They use the year-end market share value of executives' holdings to proxy stock option compensation and find it is positively related to firm performance. To the best of our knowledge, $\mathrm{Li}$ and Liu (2010), Yu (2011) and Lv et al. (2011) are the only research on the determinants of the introduction of stock options in China. All these studies find that firms with dispersed ownership are more likely to issue stock options. Specifically, Li and Liu (2010) documents that stock options are used more often by the firms facing liquidity constraints and by the firms with younger management team. Yu (2011) reports that the probability of granting stock options increases with executives' bonus and firm size, but decreases with firms' risk. Lv et al. (2011) find that firms with larger size, more investment opportunities, more free cash flows, higher executives' bonus, more executive ownership, younger management team, in highly market-oriented areas, and in less regulated industries are more likely to use stock options. 


\section{RESEARCH DESIGN}

\section{Data and Sample}

Our initial sample comprises 318 draft stock option plans announced by Chinese listed firms during the period January 2006 and June 2013. The initial sample by chance does not include any financial firms. Till June 2013, since sixteen of the sample plans are still half way in their approval procedure and haven't been implemented, they are excluded from our initial sample. Eighty-three of the plans in the sample were canceled after the announcement. If a plan is canceled after its grant date, it is kept in our sample, because in essence, the stock option plan has already obtained necessary authorization and approval and been implemented by the firm. This is the case for 9 of the suspensions. The other 74 plans are canceled without implementation and therefore are excluded from the remainder of our analysis. Another 3 plans are excluded as they are granted by ST firms ${ }^{3}$. The final sample contains 225 option grants implemented by 212 different firms.

Inquiring the reason of the suspensions, we find that the Memorandums have tightened the rules regarding exercise conditions, target grantees, intervals of material matters, and change or cancellation of incentive stock options. Specifically, firms are prohibited from modifying the exercise price or form of the original plans. Instead, they may cancel old options and reissue new options until six months after the termination. Many listed companies cancel their prior option plans when terms of the draft plans conflict with the subsequent stricter restrictions. China's Enterprises Accounting Standards No. 11 requires the recognition of the fair value of ESOs as a cost. Huge compensation cost may result in the reduction of earnings and the potential failure to satisfy the performance condition. For example, Talkweb Information System Co terminated its option plan due to fail to meet the ESO performance criteria. Since 2008, the slump in stock prices makes outstanding options out-of-the money, and in turn prompts many companies to cancel and reissue the stock options.

All financial data is collected from the CSMAR database except for bank interest rates, original cost of fixed assets, and cash dividend, which are obtained from the RESSET database. Information about the characteristics of option plans (including the grant, vesting and expiration dates, exercise price, and the total number of options granted to managers and employees) is obtained from the CSMAR database. For cases with incomplete disclosure, we manually collect data from the companies' Option Grant Notices available on the websites of Shanghai Stock Exchange and Shenzhen Stock Exchange.

\section{Variables and Model}

This paper is to investigate determinants of the scope of stock option plans. The scope of stock option can be measured by two variables: OVERHANG and BSMV. OVERHANG is the number of the target stock involved in the option plan as a fraction of the outstanding shares at grant date, while BSMV is the Black-Scholes value of the option plan as a percentage of the market value of equity at grant date. As ESO grantees could include directors and executives holding senior management roles and key technical (business) personnel, we measure the proportion of the aggregate target stock to the total equity of the company (variable: OVERHANG1) as well as the proportion of shares for different positions (variable OVERHANG2 for directors and senior executives and variable OVERHANG3 for technical and business personnel). In China, firms can choose to grant stock options once for all or by installment. Some firms reserve shares (normally equal to or less than $10 \%$ of total target shares) to special talents introduced in the future. Specifically we use OVERHANG4 to measure the proportion of reserved shares. Since stock options in China are protected against dividend payments, we use the Black Scholes (1973) model to estimate stock option values. In China, a typical option will vest in three equal installments: one-third on each of the next three anniversaries of grant date. Time to maturity is estimated as the time period between each exercisable date and grant date. The risk-free interest rate is the continuously compounded annualized bank deposit rate prevailing on grant date with duration closest to time to maturity. Volatility is estimated as square root of the sample variance of daily logarithmic stock returns over 120 trading days preceding the option grant, multiplied by 240 , number of trading days in a typical year. The number of shares involved in the stock option (assuming all the shares are exercisable), exercise price, and share price on grant date are all used as reported by the company. The total value of stock options is their Black-Scholes value multiplied by the total number of shares involved in the stock option plan. BSMV is the total Black-Scholes value divided by the market value of equity. 
We select the following explanatory variables based on prior discussion.

1. Ownership structure variables include managerial ownership (EXECOWN), blockholder ownership (LSH), institutional ownership (INSTIT), foreign ownership (FOREOWN), and state ownership (STATEOWN). We also decompose state-controlled firms into SAMBs (SAMB) and SOEs (SOE) to find differences in the scope of stock option between these groups.

2. Monitoring difficulties are proxied by firm size (FSIZE), capital-to-sales ratio (CAPTOSAL), firm focus (FOCUS), book-to-market ratio (BTOM), and firm risk (TOTRISK). Following Liljeblom et al. (2011), we divide total risk into systematic risk (SYSRISK) and unsystematic risk (UNSYSRISK) components and firm focus into mature (MATURE) and growth (GROWTH) industries to study their influence.

3. We use dividend dummy variable (DIVD) to measure short term liquidity constraints and leverage (LDEBTTOASS) to measure long term financial constraints.

4. Since Tobin's Q is significantly correlated with our growth opportunities variable BTOM, we instead use prior stock returns (PRETURN) and cash flow-to-assets ratio (CFTOASS) as proxies of firm performance. According to Liljeblom et al. (2011), cash flow-to-assets may also control for the agency costs due to free cash flow problem.

5. Indicator variables included are prior plan (PRPLAN) and broad-based plan (BBPLAN).

The definition and measurement of the variables are listed in Appendix.

Specifically, the dependent variables (OVERHANG1, OVERHANG2, OVERHANG3, OVERHANG4, and BSMV, respectively) of this study are regressed on the aforementioned explanatory variables using this regression model:

$$
\begin{aligned}
& y_{t}={ }_{0}+{ }_{1} \text { EXECOWN }_{t-1}+{ }_{2} \text { LSH }_{t-1}+{ }_{3} \text { INSTIT }_{t-1}+{ }_{4} \text { FOREOWN }_{t-1}+{ }_{5} \text { STATEOWN }_{t-1}+{ }_{6} \text { FSIZE }_{t-1}+{ }_{7} \text { CAPTOSAL }_{t 1} \\
& +{ }_{8} \text { FOCUS }_{t-1}+{ }_{9} \text { BTOM }_{t-1}+{ }_{10} \text { TOTRISK }_{t-1}+{ }_{11} \text { DIVD }_{t-1}+{ }_{12} \text { LDEBTTOASS }_{t-1}+{ }_{13} \text { PRETURN }_{t}+{ }_{14} \text { CFTOASS }_{t-1} \\
& +{ }_{15} \text { PRPLAN }_{t-1}+{ }_{16} \text { BBPLAN }_{t-1}+\text { year dummies }+{ }_{t}
\end{aligned}
$$

Where $y_{t}$ are the five dependent variables used, separately, in five different regressions. The right-hand side variables are lagged one year in order to capture firm characteristics prior to the design of stock option plan. Year dummies are included in all regressions but not reported. When BSMV is the dependent variable, risk variables (TOTRISK, SYSRISK and UNSYSRISK) are excluded from the independent variables because historical standard deviation of stock returns is a parameter in Black-Scholes value calculation. Model (1) is the base case model, with STATEOWN, FOCUS and TOTRISK at their aggregate level. STATEOWN, FOCUS and TOTRISK are replaced with their decomposed components (i.e. SAMB and SOE for STATEOWN; MATURE and GROWTH for FOCUS; SYSRISK and UNSYSRISK for TOTRISK) in models (2) and (5), models (3) and (5), and models (4) and (5), respectively. 


\section{EMPIRICAL ANALYSIS}

\section{Descriptive Statistics}

Table 1. Sample characteristics

\begin{tabular}{|c|c|c|}
\hline \multicolumn{3}{|c|}{ Panel A. Final sample of option plan adoptions by year } \\
\hline Grant year & Total number of option plan adoptions & Percentage of sample $(\%)$ \\
\hline 2006 & 12 & $5.33 \%$ \\
\hline 2007 & 3 & $1.33 \%$ \\
\hline 2008 & 13 & $5.78 \%$ \\
\hline 2009 & 8 & $3.56 \%$ \\
\hline 2010 & 25 & $11.11 \%$ \\
\hline 2011 & 71 & $31.56 \%$ \\
\hline 2012 & 80 & $35.56 \%$ \\
\hline 2013 & 13 & $5.78 \%$ \\
\hline Total & 225 & $100.00 \%$ \\
\hline
\end{tabular}

Panel B. Number of option plan adoptions per firm

\begin{tabular}{|c|c|c|}
\hline Number of plans & Number of firms & Percentage (\%) \\
\hline 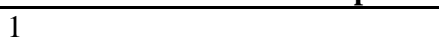 & 200 & $94.34 \%$ \\
\hline 2 & 11 & $5.19 \%$ \\
\hline 3 & 1 & $0.47 \%$ \\
\hline Total & 212 & $100.00 \%$ \\
\hline
\end{tabular}

Panel C: Industry distribution

\begin{tabular}{lcr}
\hline & Number of firms & Percentage (\%) \\
\hline Agricultural, forest, animal husbandry and fishery & 5 & $2.2 \%$ \\
Mining & 1 & $0.4 \%$ \\
Manufacturing & 129 & $57.3 \%$ \\
Electricity gas and water & 1 & $0.4 \%$ \\
Construction & 7 & $3.1 \%$ \\
Information technology & 47 & $20.9 \%$ \\
Wholesale and retail & 9 & $4.0 \%$ \\
Real estate & 12 & $5.3 \%$ \\
Social service & 7 & $3.1 \%$ \\
Communication and culture & 4 & $1.8 \%$ \\
Industrial conglomerates & 3 & $1.3 \%$ \\
Total & 225 & $100.0 \%$ \\
\hline
\end{tabular}

Table 1 reports characteristics of our final sample, which contains 225 option grants implemented by 212 different firms. Panel A shows the timing of the stock option plans for the sample from January 2006 to June 2013. There were only three option launches in year 2007 because in that year listed companies were required to strengthen corporate governance and most of the ESO applications were suspended. A large number of stock options were launched in the period between the years 2010 and 2012 when China's stock market was amid a persistent slump. The Chinese evidence is in sharp contrast with Liljeblom et al. (2011)'s finding that Finland option launches diminish with the decline in market values. Our finding indicates that managers intentionally choose the right time when exercise price is low and potential option value is high. Panel B shows that 212 different firms are associated with the 225 grants. During our sample period, 94 percent of the firms launched stock option plans only once. According to "Listing Corporation Industry Classification Guide (LCICG) (2001)", Chinese firms are divided into 11 industries as shown in Panel C of Table $1^{4}$. It shows the sample firms are concentrated in manufacturing (57\%) and information technology (21\%) industries. If a firm belongs to the industrial conglomerates industry, we classify it as diversified (variable FOCUS $=0$ ); while if a firms belongs to the other 10 industries, we classify it as focused (variable FOCUS = 1). In our sample, only three options are granted by diversified firms. Based on 2-digit industrial classification code from LCICG, we further decompose the firms in the focused category into mature and growth industries. Although not reported, our data reveal that $134(60 \%)$ stock options are launched by firms in mature industries and $88(39 \%)$ are launched by firms in growth industries. 
Table 2. Descriptive statistics

\begin{tabular}{|c|c|c|c|c|c|}
\hline $\begin{array}{l}\text { Variables } \\
\text { Stock option plan characteristics }\end{array}$ & Mean & Median & $\begin{array}{l}\text { Standard } \\
\text { Deviation }\end{array}$ & Minimum & Maximum \\
\hline Premium & 0.026 & 0.026 & 0.359 & -0.751 & 2.234 \\
\hline Term [in years] & 4.596 & 4.000 & 0.926 & 3.000 & 10.000 \\
\hline Vesting period [in years] & 3.506 & 3.300 & 0.742 & 1.900 & 8.500 \\
\hline $\begin{array}{l}\text { Total shares granted [\% of outstanding } \\
\text { shares] }\end{array}$ & $3.5 \%$ & $3.0 \%$ & $2.3 \%$ & $0.2 \%$ & $10.0 \%$ \\
\hline $\begin{array}{l}\text { Shares granted to directors and senior } \\
\text { executives [\% of outstanding shares] }\end{array}$ & $1.0 \%$ & $0.5 \%$ & $1.2 \%$ & $0.0 \%$ & $6.8 \%$ \\
\hline $\begin{array}{l}\text { Shares granted to technical and business } \\
\text { personnel [\% of outstanding shares] }\end{array}$ & $2.3 \%$ & $2.0 \%$ & $1.7 \%$ & $0.0 \%$ & $8.2 \%$ \\
\hline Reserved shares [\% of outstanding shares] & $0.1 \%$ & $0.0 \%$ & $0.2 \%$ & $0.0 \%$ & $0.9 \%$ \\
\hline $\begin{array}{l}\text { Total Black-Sholes value of option plan } \\
{[¥ 000]}\end{array}$ & 87556 & 43111 & 141533 & 3100 & 1059261 \\
\hline $\begin{array}{l}\text { Call option value of option plan to market } \\
\text { value of equity }\end{array}$ & 0.013 & 0.010 & 0.012 & 0.001 & 0.065 \\
\hline $\begin{array}{l}\text { Shares granted to directors and senior } \\
\text { executives [\% of total granted shares] }\end{array}$ & $26.1 \%$ & $21.2 \%$ & $21.5 \%$ & $0.0 \%$ & $100.0 \%$ \\
\hline $\begin{array}{l}\text { Shares granted to technical and business } \\
\text { personnel [\% of total granted shares] }\end{array}$ & $69.1 \%$ & $72.5 \%$ & $21.0 \%$ & $0.0 \%$ & $100.0 \%$ \\
\hline Reserved shares [\% of total granted shares] & $4.2 \%$ & $0.0 \%$ & $4.7 \%$ & $0.0 \%$ & $13.3 \%$ \\
\hline \multicolumn{6}{|l|}{ Ownership variables } \\
\hline $\begin{array}{l}\text { EXECOWN } \\
\text { LSH } \\
\text { INSTIT } \\
\text { FOREOWN }[1 / 0] \\
\text { STATEOWN } \\
\text { SAMB }[1 / 0] \\
\text { SOE }[1 / 0] \\
\text { Firm characteristics } \\
\end{array}$ & $\begin{array}{l}0.154 \\
0.327 \\
0.187 \\
0.173 \\
0.039 \\
0.107 \\
0.013\end{array}$ & $\begin{array}{l}0.006 \\
0.307 \\
0.138 \\
0.000\end{array}$ & $\begin{array}{l}0.225 \\
0.175 \\
0.168 \\
0.124\end{array}$ & $\begin{array}{l}0.000 \\
0.000 \\
0.000 \\
0.000\end{array}$ & $\begin{array}{l}0.735 \\
0.806 \\
0.889 \\
0.722\end{array}$ \\
\hline Total Assets [ $¥ 000]$ & 6741697 & 1681846 & 22185338 & 367644 & 215637552 \\
\hline $\begin{array}{l}\text { CAPTOSAL } \\
\text { FOCUS [1/0] } \\
\text { MATURE [1/0] } \\
\text { GROWTH [1/0] }\end{array}$ & $\begin{array}{l}0.347 \\
0.987 \\
0.596 \\
0.391\end{array}$ & 0.286 & 0.300 & 0.0001 & 2.017 \\
\hline BTOM & 0.636 & 0.615 & 0.232 & 0.124 & 1.726 \\
\hline TOTRISK & 0.164 & 0.080 & 0.662 & 0.035 & 8.906 \\
\hline SYSRISK & 0.031 & 0.025 & 0.024 & 0.004 & 0.172 \\
\hline UNSYSRISK & 0.133 & 0.052 & 0.659 & 0.014 & 8.895 \\
\hline DIVD [1/0] & 0.831 & & & & \\
\hline LDEBTTOASS & 0.036 & 0.000 & 0.080 & 0.000 & 0.448 \\
\hline PRETURN & -0.151 & -0.199 & 0.612 & -1.733 & 1.833 \\
\hline CFTOASS & 0.096 & 0.091 & 0.048 & -0.032 & 0.376 \\
\hline PRPLAN [1/0] & 0.058 & & & & \\
\hline BBPLAN [1/0] & 0.920 & & & & \\
\hline
\end{tabular}


Table 2 describes sample statistics for stock option characteristics, ownership variables and firm characteristics. The statistics for stock option premium reveal that the average (and also the median) exercise price is 3\% higher than the stock price at grant date, suggesting that in China, stock options are granted out-of-the-money. Cross-sectionally, only one option is granted at-the-money. There are 123 options (55\% of the total sample) with positive premium and 101 options (45\% of the total sample) with negative premium. This is in sharp contrast with stock options in other countries. For the U.S., stock options are almost always granted at-the-money (Kole, 1997; Murphy, 1999). For Japan and Finland, the stock option premium is 5\% and 10\%, respectively (Kato et al., 2005; Liljeblom et al., 2011). Options in our sample have a term between three to ten years. The average 4.6 years of timeto-maturity is closer to that in Japan (five years) and Finland (six years) but much shorter than a typical ten-year lives in U.S. (Kato et al., 2005; Liljeblom et al., 2011). In China, stock options are required to include a minimum one year vesting period. A typical option will vest in three equal installments after minimum waiting period. The average vesting period is 3.5 years. The Measures requires the total number of shares granted as options not exceed $10 \%$ of the outstanding shares. The total stock option overhang in our sample is within the range of $0.2 \%$ to $10 \%$, with an average value of 3.5\%. The average total Black-Sholes value is RMB 87,556,000 and the average ratio of total Black-Scholes value to market value of equity is $1.3 \%$. In China, most of the stock options are awarded not only to directors and senior executives, but also to technical and business personnel. Of the 225 sample stock options, except for four (1.8\%) stock options granted solely to directors and senior executives and five (2.2\%) stock options awarded solely to technical and business personnel, the rest stock options are broad-based. Although we do not have specific data for the number of target grantees, the number of employee plan participants is larger than that of senior executives at large. As a result, the average number of shares for all top management is $1 \%$ of outstanding shares ( $26.1 \%$ of total granted shares), whereas, the average number of shares for all middle level employees is $2.3 \%$ of outstanding shares (69.1\% of total granted shares). Some companies also issue reserved stock options to attract special talents in the future. In our sample, less than half (104 cases) of companies have reserved shares and the amount is small with a mean value of $0.1 \%(4.2 \%)$ of outstanding shares (total granted shares).

As space is limited, the correlations among the explanatory variables are calculated but not reported. Multicollinearity is not a serious problem here. Most of the correlations are less than 0.5. STATEOWN and SAMB is highly correlation. The same is for variables TOTRISK and UNSYSRISK. This is not surprising, given that SAMB (UNSYSRISK) is the dominant component in STATEOWN (TOTRISK). This is not a major issue for our regression analysis because we do not use these variables together in a regression. MATURE is correlated negatively and significantly with GROWTH (i.e. $-97.3 \%$ ). This may be of some concern and will be addressed when presenting the multivariate analysis results.

\section{Regression Results}

Determinants of the Scope of Stock Option Plans

Table 3 presents the regression results from the determinants of the scope of stock option plans. We begin our analysis by examining the determinants of total option grants to all of the recipients, using total stock option overhang as dependent variable. As specified earlier, five models (Models (1) to (5) of Equation (1)) are estimated and the estimation results are reported in Panel A. Panel B presents the regression results using the ratio of total Black-Scholes value to market value of equity as a measure of the scope of stock option. As mentioned before, risk variables are excluded from the independent variables in BSMV regressions and four model specifications are

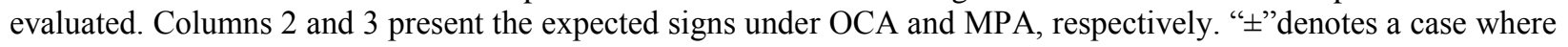
theoretical arguments exist for both positive and negative effects; whereas "?" denotes a case where theoretical predictions of the signs are ambiguous. 
Table 3. Determinants of the scope of stock option plans

\begin{tabular}{|c|c|c|c|c|c|c|c|}
\hline \multicolumn{8}{|c|}{ Panel A: OVERHANG1 (Total stock option overhang) } \\
\hline \multirow[t]{2}{*}{$\begin{array}{c}\text { Independent } \\
\text { variable }\end{array}$} & \multirow[t]{2}{*}{$\begin{array}{c}\text { Expected } \\
\text { sign (OCA) }\end{array}$} & \multirow[t]{2}{*}{$\begin{array}{c}\text { Expected } \\
\text { sign (MPA) } \\
\end{array}$} & \multicolumn{5}{|c|}{ Dependent Variable } \\
\hline & & & Model 1 & Model 2 & Model 3 & Model 4 & Model 5 \\
\hline Constant & & & $\begin{array}{c}0.183 * * * \\
(5.348) \\
\end{array}$ & $\begin{array}{c}0.140 * * * \\
(4.088)\end{array}$ & $\begin{array}{c}0.182 * * * \\
(5.223)\end{array}$ & $\begin{array}{c}0.186 * * * \\
(5.501) \\
\end{array}$ & $\begin{array}{c}0.148 * * * \\
(4.330)\end{array}$ \\
\hline EXECOWN & - & + & $\begin{array}{c}-0.017 * * \\
(-2.360)\end{array}$ & $\begin{array}{c}-0.017 * * \\
(-2.259)\end{array}$ & $\begin{array}{c}-0.017 * * \\
(-2.353)\end{array}$ & $\begin{array}{c}-0.018^{* *} \\
(-2.429)\end{array}$ & $\begin{array}{c}-0.017 * * \\
(-2.311)\end{array}$ \\
\hline LSH & - & - & $\begin{array}{c}-0.018^{*} \\
(-1.920) \\
\end{array}$ & $\begin{array}{c}-0.021^{* *} \\
(-2.085) \\
\end{array}$ & $\begin{array}{l}-0.018^{*} \\
(-1.916) \\
\end{array}$ & $\begin{array}{c}-0.021^{* *} \\
(-2.163) \\
\end{array}$ & $\begin{array}{c}-0.023 * * \\
(-2.373) \\
\end{array}$ \\
\hline INSTIT & - & - & $\begin{array}{c}0.004 \\
(0.434) \\
\end{array}$ & $\begin{array}{c}0.001 \\
(0.143) \\
\end{array}$ & $\begin{array}{c}0.004 \\
(0.421) \\
\end{array}$ & $\begin{array}{c}0.003 \\
(0.306) \\
\end{array}$ & $\begin{array}{c}0.001 \\
(0.052) \\
\end{array}$ \\
\hline FOREOWN & - & - & $\begin{array}{c}-0.011 \text { **** } \\
(-3.168)\end{array}$ & $\begin{array}{c}-0.009 * * * \\
(-2.956)\end{array}$ & $\begin{array}{c}-0.010 * * * \\
(-3.164) \\
\end{array}$ & $\begin{array}{c}-0.011 * * * \\
(-3.240) \\
\end{array}$ & $\begin{array}{c}-0.010 \text { **** } \\
(-3.075) \\
\end{array}$ \\
\hline STATEOWN & $?$ & - & $\begin{array}{c}-0.048 * * * \\
(-4.309) \\
\end{array}$ & & $\begin{array}{c}-0.048 * * * \\
(-4.280) \\
\end{array}$ & $\begin{array}{c}-0.052 * * * \\
(-4.556) \\
\end{array}$ & \\
\hline SAMB & & $?$ & & $\begin{array}{c}-0.027 * * * \\
(-5.155) \\
\end{array}$ & & & $\begin{array}{c}-0.028 * * * \\
(-5.240) \\
\end{array}$ \\
\hline SOE & & $?$ & & $\begin{array}{c}0.007 \\
(0.912) \\
\end{array}$ & & & $\begin{array}{c}0.010 \\
(1.168) \\
\end{array}$ \\
\hline FSIZE & + & & $\begin{array}{c}-0.005 * * * \\
(-3.284)\end{array}$ & $\begin{array}{c}-0.003^{*} \\
(-1.892)\end{array}$ & $\begin{array}{c}-0.005^{* * *} \\
(-3.176)\end{array}$ & $\begin{array}{c}-0.005 * * * \\
(-3.123)\end{array}$ & $\begin{array}{c}-0.003^{*} \\
(-1.829)\end{array}$ \\
\hline CAPTOSAL & - & & $\begin{array}{c}-0.006 \\
(-1.000)\end{array}$ & $\begin{array}{c}-0.006 \\
(-1.152)\end{array}$ & $\begin{array}{c}-0.006 \\
(-0.991)\end{array}$ & $\begin{array}{c}-0.005 \\
(-0.925)\end{array}$ & $\begin{array}{c}-0.006 \\
(-1.162)\end{array}$ \\
\hline FOCUS & - & & $\begin{array}{c}-0.020 \\
(-1.615)\end{array}$ & $\begin{array}{c}-0.015 \\
(-1.299)\end{array}$ & & $\begin{array}{c}-0.022^{* * *} \\
(-1.974)\end{array}$ & \\
\hline MATURE & $?$ & & & & $\begin{array}{c}-0.020 \\
(-1.612) \\
\end{array}$ & & $\begin{array}{c}-0.017 \\
(-1.593) \\
\end{array}$ \\
\hline GROWTH & $?$ & & & & $\begin{array}{c}-0.019 \\
(-1.561) \\
\end{array}$ & & $\begin{array}{l}-0.019^{*} \\
(-1.742) \\
\end{array}$ \\
\hline BTOM & - & & $\begin{array}{c}0.021 * * \\
(2.223)\end{array}$ & $\begin{array}{l}0.015^{*} \\
(1.860) \\
\end{array}$ & $\begin{array}{c}0.021 * * \\
(2.215) \\
\end{array}$ & $\begin{array}{c}0.021^{* *} \\
(2.182) \\
\end{array}$ & $\begin{array}{l}0.014 * \\
(1.814) \\
\end{array}$ \\
\hline TOTRISK & $+/-$ & & $\begin{array}{l}0.002 * \\
(1.945) \\
\end{array}$ & $\begin{array}{l}0.002 * \\
(2.035)\end{array}$ & $\begin{array}{l}0.002 * \\
(1.930)\end{array}$ & & \\
\hline SYSRISK & $?$ & & & & & $\begin{array}{c}-0.209 * * \\
(-2.432)\end{array}$ & $\begin{array}{c}-0.197 * * \\
(-2.350) \\
\end{array}$ \\
\hline UNSYSRISK & $?$ & & & & & $\begin{array}{l}0.002 * \\
(1.944) \\
\end{array}$ & $\begin{array}{l}0.002 * \\
(1.886)\end{array}$ \\
\hline DIVD & - & & $\begin{array}{l}-0.009 * \\
(-1.900)\end{array}$ & $\begin{array}{c}-0.009 * * \\
(-2.121)\end{array}$ & $\begin{array}{l}-0.009 * \\
(-1.893)\end{array}$ & $\begin{array}{l}-0.008^{*} \\
(-1.787)\end{array}$ & $\begin{array}{l}-0.008^{*} \\
(-1.891)\end{array}$ \\
\hline LDEBTTOASS & - & & $\begin{array}{c}0.023 \\
(0.875) \\
\end{array}$ & $\begin{array}{c}0.025 \\
(0.938) \\
\end{array}$ & $\begin{array}{c}0.023 \\
(0.880) \\
\end{array}$ & $\begin{array}{c}0.022 \\
(0.867) \\
\end{array}$ & $\begin{array}{c}0.024 \\
(0.901) \\
\end{array}$ \\
\hline PRETURN & + & & $\begin{array}{c}0.008 * * * \\
(2.687)\end{array}$ & $\begin{array}{c}0.008 * * * \\
(2.658)\end{array}$ & $\begin{array}{c}0.008 * * * \\
(2.712)\end{array}$ & $\begin{array}{c}0.008 * * \\
(2.593)\end{array}$ & $\begin{array}{c}0.007 * * \\
(2.490)\end{array}$ \\
\hline CFTOASS & + & & $\begin{array}{c}0.021 \\
(0.662) \\
\end{array}$ & $\begin{array}{c}0.005 \\
(0.175) \\
\end{array}$ & $\begin{array}{c}0.022 \\
(0.682) \\
\end{array}$ & $\begin{array}{c}0.010 \\
(0.306) \\
\end{array}$ & $\begin{array}{c}-0.011 \\
(-0.376) \\
\end{array}$ \\
\hline PRPLAN & - & & $\begin{array}{c}0.002 \\
(0.404) \\
\end{array}$ & $\begin{array}{l}0.0001 \\
(0.015) \\
\end{array}$ & $\begin{array}{c}0.002 \\
(0.403) \\
\end{array}$ & $\begin{array}{c}0.002 \\
(0.318) \\
\end{array}$ & $\begin{array}{l}-0.0003 \\
(-0.049) \\
\end{array}$ \\
\hline BBPLAN & + & & $\begin{array}{c}0.013 * * * \\
(3.521)\end{array}$ & $\begin{array}{c}0.014 * * * \\
(3.779)\end{array}$ & $\begin{array}{c}0.013 * * * \\
(3.553)\end{array}$ & $\begin{array}{c}0.014 * * * \\
(3.692)\end{array}$ & $\begin{array}{c}0.015^{* * *} \\
(3.938) \\
\end{array}$ \\
\hline Year dummies & & & Yes & Yes & Yes & Yes & Yes \\
\hline Adjusted $\mathrm{R}^{2}$ & & & 0.323 & 0.364 & 0.319 & 0.332 & 0.369 \\
\hline no. of obs. & & & 218 & 218 & 218 & 218 & 218 \\
\hline
\end{tabular}


(Table 3 continued)

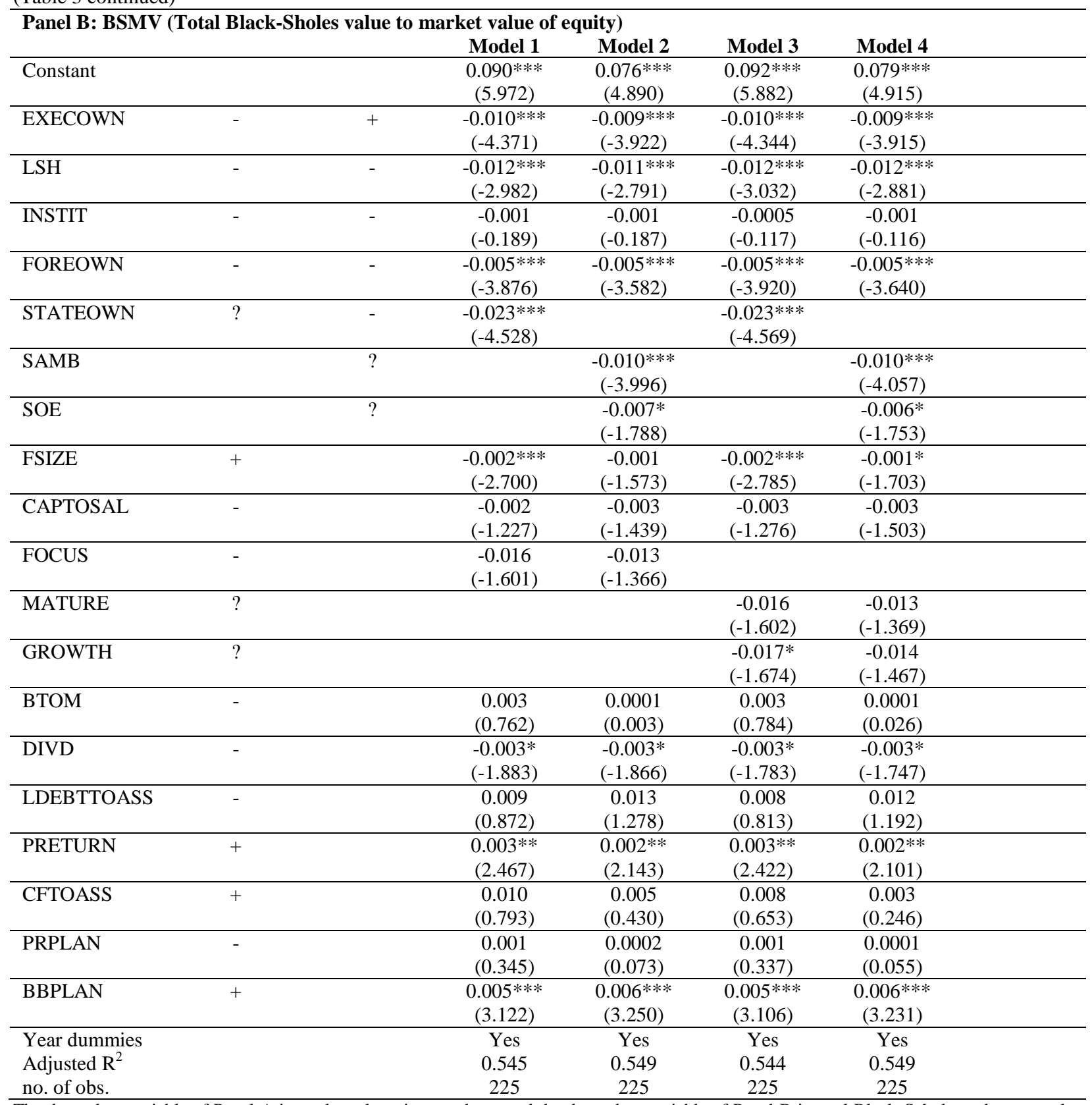

The dependent variable of Panel A is total stock option overhang and the dependent variable of Panel B is total Black-Scholes value to market value of equity. All of the independent variables are lagged one year. Definitions of each variable are given in Appendix. All risk measures are multiplied by 100 for presentation in the table. Figures in parentheses are t-statistics. Year dummies are included in all regressions but not reported. * refers to significance at the 10 percent level; ** refers to significance at the 5 percent level; and *** refers to significance at the 1 percent level.

From Panel A, we find that managerial ownership has a negative and significant coefficient, suggesting a substitution effect between managerial stock ownership and stock option compensation. This result contradicts the entrenchment hypothesis that firms with higher managerial ownership tend to use more stock options. The coefficients for blockholder ownership and foreign ownership are uniformly negative and significant in all the model specifications. These results are consistent with both OCA and MPA, in that monitoring incentives of blockholders and foreign shareholders substitute for the incentives provided by stock options or stronger shareholder monitoring alleviates managerial rent extraction problem and thus reduces the need for granting stock option to managers. The 
coefficient on institutional ownership is positive but insignificant. The coefficient on state ownership is significantly negative as expected, indicating that option programs in Chinese state-owned firms are restrictive. As explained with MPA, political pressure may constrain top executive compensation in state-owned firms. Furthermore, most senior executives in state-controlled firms are more likely to be bureaucrats with lower managerial quality (Firth et al., 2006) and thus they tend to value perks and job promotion more than high-powered stock options. The coefficient for SAMB is significantly negative, indicating that aforementioned explanation is especially true for the firms controlled by SAMBs.

As for monitoring costs measures, our results reveal that firm size significantly decreases the scope of stock option, whereas book-to-market ratio significantly increases the scope of stock option. In addition capital-to-sales ratio seems to have no effect on the scope of stock option. These results contradict the OCA predictions that firms with a high level of monitoring costs (large firm size, a low book-to-market ratio, and a low capital-to-sales) use more stock option incentives. Liljeblom et al. (2011) and Oyer and Schaefer (2005) also report an inverse relation between the scope of option plans and firm size and explain it as CEO productivity increases at a decreasing rate with firm size. In our sample, firm size and state ownership are positively correlated. Based on our sample, another possible interpretation of this inverse relation is that small firms may use stock option as a signaling device to investors but large firms (especially SOEs) undergoing high public scrutiny tend to use less stock options to ensure managers' compensation not exceptionally high. The positive coefficients for book-to-market ratio are inconsistent with the OCA prediction but consistent with previous empirical evidence (e.g., Yermarck, 1995). There is weak evidence that firms with high degree of monitoring difficulties are more likely to use stock option plans, as the coefficients on firm focus are negative, but only significant in one specification. When the firm focus variable is decomposed into mature industry and growth industry indicators, we find that both indicators are negatively related to total stock option overhang, although only growth industry indicator is significant in one specification. Our data reveal that total risks and unsystematic risks significantly increase the scope of stock option, whereas systematic risks significantly decrease the scope of stock option. This finding suggests that management risk aversion dominants interest alignment needs when systematic risks are high, while the case is opposite when firm specific risks are high. When economic significance is concerned, the effect of systematic risk is about 100 times of that of unsystematic risk.

Consistent with our OCA predictions, we find that stock option awards are significantly greater for dividend-constrained firms, better performing firms, and firms launching broad-based option plans. These finding can be interpreted as evidence that firms make greater use of equity-based compensation to conserve cash. Firms with good past performance (a higher prior return) tend to grant managers more options as a reward for past behavior. It is a natural finding that a large target group obtains a greater scope in aggregate. Finally, the results from Panel A of Table 3 suggest that institutional ownership, capital-to-sales ratio, leverage, cash flow-to-assets ratio, and prior plan do not seem to be associated with the scope of stock option plans.

Panel B presents the results with BSMV as dependent variable instead of OVERHANG1. The explanation power of BSMV regressions is higher than that of OVERHANG1 regressions, while the coefficients for the explanatory variables are similar in significance but smaller in magnitude. The associations between ownership variables and BSMV are largely consistent with the results in Panel A. Similar to our results in Panel A, firm size and dividend dummy variable are negative and significant in Panel B. Furthermore, prior return and broad-based plan are also significantly positive as expected in Panels B. The results in Panels B differ from those in Panel A in following aspects: The coefficients for SOE become significant at $10 \%$ level in Panel B; Both firm focus and bookto-market ratio now lose significance.

Table 4 extends the analysis to examine the determinants of stock options to different target grantees: Panel A for directors and senior executives and Panel B for technical and business personnel. Moreover, we investigate the factors associated with stock option overhang for reserved shares and report the results in Panel C. 
Table 4. Determinants of the scope of stock option plans by type of recipients

\begin{tabular}{|c|c|c|c|c|c|c|c|}
\hline \multicolumn{8}{|c|}{ Panel A: OVERHANG2 (Stock option overhang for directors and senior executives) } \\
\hline Variable & $\begin{array}{c}\text { Expected } \\
\text { sign (OCA) }\end{array}$ & $\begin{array}{c}\text { Expected } \\
\text { sign (MPA) }\end{array}$ & Model 1 & Model 2 & Model 3 & Model 4 & Model 5 \\
\hline Constant & & & $\begin{array}{c}0.096 * * * \\
(5.307)\end{array}$ & $\begin{array}{c}0.085 * * * \\
(4.737) \\
\end{array}$ & $\begin{array}{c}0.098 * * * \\
(5.491) \\
\end{array}$ & $\begin{array}{c}0.100 * * * \\
(5.662)\end{array}$ & $\begin{array}{c}0.095^{* * * *} \\
(5.382) \\
\end{array}$ \\
\hline EXECOWN & - & + & $\begin{array}{c}-0.006^{* *} \\
(-2.103)\end{array}$ & $\begin{array}{l}-0.005^{*} \\
(-1.857)\end{array}$ & $\begin{array}{c}-0.006 * * \\
(-2.100)\end{array}$ & $\begin{array}{c}-0.006 * * \\
(-2.140)\end{array}$ & $\begin{array}{l}-0.005^{*} \\
(-1.859)\end{array}$ \\
\hline LSH & - & - & $\begin{array}{c}-0.003 \\
(-0.862) \\
\end{array}$ & $\begin{array}{c}-0.002 \\
(-0.674) \\
\end{array}$ & $\begin{array}{c}-0.003 \\
(-0.899) \\
\end{array}$ & $\begin{array}{c}-0.005 \\
(-1.287) \\
\end{array}$ & $\begin{array}{c}-0.004 \\
(-1.176) \\
\end{array}$ \\
\hline INSTIT & - & - & $\begin{array}{c}0.006 \\
(1.237) \\
\end{array}$ & $\begin{array}{c}0.005 \\
(0.902) \\
\end{array}$ & $\begin{array}{c}0.007 \\
(1.260) \\
\end{array}$ & $\begin{array}{c}0.006 \\
(1.191) \\
\end{array}$ & $\begin{array}{c}0.005 \\
(0.878) \\
\end{array}$ \\
\hline FOREOWN & - & - & $\begin{array}{c}-0.001 \\
(-0.841) \\
\end{array}$ & $\begin{array}{c}-0.001 \\
(-0.735) \\
\end{array}$ & $\begin{array}{c}-0.002 \\
(-0.903) \\
\end{array}$ & $\begin{array}{c}-0.002 \\
(-0.908) \\
\end{array}$ & $\begin{array}{c}-0.002 \\
(-0.949) \\
\end{array}$ \\
\hline STATEOWN & $?$ & - & $\begin{array}{c}-0.015 * * * \\
(-2.821) \\
\end{array}$ & & $\begin{array}{c}-0.015 * * * \\
(-2.812) \\
\end{array}$ & $\begin{array}{c}-0.017 * * * \\
(-3.173)\end{array}$ & \\
\hline SAMB & & $?$ & & $\begin{array}{c}-0.006 * * * \\
(-2.744)\end{array}$ & & & $\begin{array}{c}-0.007 * * * \\
(-2.891)\end{array}$ \\
\hline SOE & & $?$ & & $\begin{array}{c}0.006 * * \\
(2.333) \\
\end{array}$ & & & $\begin{array}{c}0.008 * * * \\
(2.882) \\
\end{array}$ \\
\hline FSIZE & + & & $\begin{array}{c}-0.002 * * * \\
(-3.117)\end{array}$ & $\begin{array}{c}-0.002 * * \\
(-2.478)\end{array}$ & $\begin{array}{c}-0.003 * * * \\
(-3.194)\end{array}$ & $\begin{array}{c}-0.002 * * * \\
(-3.096)\end{array}$ & $\begin{array}{c}-0.002 * * \\
(-2.685)\end{array}$ \\
\hline CAPTOSAL & - & & $\begin{array}{c}-0.002 \\
(-0.720)\end{array}$ & $\begin{array}{c}-0.002 \\
(-0.779) \\
\end{array}$ & $\begin{array}{c}-0.002 \\
(-0.774)\end{array}$ & $\begin{array}{c}-0.002 \\
(-0.689)\end{array}$ & $\begin{array}{c}-0.002 \\
(-0.898) \\
\end{array}$ \\
\hline FOCUS & - & & $\begin{array}{c}-0.013 \\
(-1.613) \\
\end{array}$ & $\begin{array}{c}-0.012 \\
(-1.462) \\
\end{array}$ & & $\begin{array}{l}-0.015^{* *} \\
(-1.994) \\
\end{array}$ & \\
\hline MATURE & $?$ & & & & $\begin{array}{c}-0.013 \\
(-1.588) \\
\end{array}$ & & $\begin{array}{l}-0.014^{*} \\
(-1.765) \\
\end{array}$ \\
\hline GROWTH & $?$ & & & & $\begin{array}{l}-0.014 * \\
(-1.698) \\
\end{array}$ & & $\begin{array}{l}-0.016 * * \\
(-2.016) \\
\end{array}$ \\
\hline BTOM & - & & $\begin{array}{c}0.012 * * \\
(2.554)\end{array}$ & $\begin{array}{c}0.010 * * \\
(2.302)\end{array}$ & $\begin{array}{c}0.012 * * \\
(2.542)\end{array}$ & $\begin{array}{c}0.013 * * * \\
(2.615) \\
\end{array}$ & $\begin{array}{c}0.010 * * \\
(2.311)\end{array}$ \\
\hline TOTRISK & $+/-$ & & $\begin{array}{c}0.001 \\
(1.285) \\
\end{array}$ & $\begin{array}{c}0.001 \\
(1.398) \\
\end{array}$ & $\begin{array}{c}0.001 \\
(1.168) \\
\end{array}$ & & \\
\hline SYSRISK & $?$ & & & & & $\begin{array}{c}-0.116^{* *} \\
(-2.434)\end{array}$ & $\begin{array}{c}-0.119 * * \\
(-2.546)\end{array}$ \\
\hline UNSYSRISK & $?$ & & & & & $\begin{array}{c}0.001 \\
(1.555) \\
\end{array}$ & $\begin{array}{c}0.001 \\
(1.335) \\
\end{array}$ \\
\hline DIVD & - & & $\begin{array}{c}-0.006 * * \\
(-2.340) \\
\end{array}$ & $\begin{array}{c}-0.006 * * \\
(-2.422) \\
\end{array}$ & $\begin{array}{c}-0.006 * * \\
(-2.202) \\
\end{array}$ & $\begin{array}{c}-0.006 * * \\
(-2.280) \\
\end{array}$ & $\begin{array}{c}-0.005 * * \\
(-2.158) \\
\end{array}$ \\
\hline LDEBTTOASS & - & & $\begin{array}{l}0.025^{*} \\
(1.904) \\
\end{array}$ & $\begin{array}{c}0.026 * * \\
(2.037) \\
\end{array}$ & $\begin{array}{l}0.024 * \\
(1.870) \\
\end{array}$ & $\begin{array}{l}0.024 * \\
(1.926) \\
\end{array}$ & $\begin{array}{c}0.024 * * \\
(2.010) \\
\end{array}$ \\
\hline PRETURN & + & & $\begin{array}{c}0.005 * * * \\
(4.151) \\
\end{array}$ & $\begin{array}{c}0.005 * * * \\
(4.253)\end{array}$ & $\begin{array}{c}0.005 * * * \\
(4.137)\end{array}$ & $\begin{array}{c}0.005 * * * \\
(4.038) \\
\end{array}$ & $\begin{array}{c}0.005^{* * * *} \\
(4.015) \\
\end{array}$ \\
\hline CFTOASS & + & & $\begin{array}{c}0.021 \\
(1.414) \\
\end{array}$ & $\begin{array}{c}0.014 \\
(0.997) \\
\end{array}$ & $\begin{array}{c}0.019 \\
(1.326) \\
\end{array}$ & $\begin{array}{c}0.016 \\
(1.046) \\
\end{array}$ & $\begin{array}{c}0.004 \\
(0.275) \\
\end{array}$ \\
\hline PRPLAN & - & & $\begin{array}{c}-0.001 \\
(-0.481)\end{array}$ & $\begin{array}{c}-0.001 \\
(-0.574) \\
\end{array}$ & $\begin{array}{c}-0.001 \\
(-0.506) \\
\end{array}$ & $\begin{array}{c}-0.001 \\
(-0.559) \\
\end{array}$ & $\begin{array}{c}-0.002 \\
(-0.685) \\
\end{array}$ \\
\hline BBPLAN & + & & $\begin{array}{c}-0.008 * * \\
(-2.250) \\
\end{array}$ & $\begin{array}{l}-0.007 * \\
(-1.852) \\
\end{array}$ & $\begin{array}{c}-0.008 * * \\
(-2.285) \\
\end{array}$ & $\begin{array}{c}-0.009 * * \\
(-2.280) \\
\end{array}$ & $\begin{array}{c}-0.008 * * \\
(-2.071) \\
\end{array}$ \\
\hline $\begin{array}{l}\text { Year dummies } \\
\text { Adjusted } \mathrm{R}^{2} \\
\text { no. of obs. }\end{array}$ & & & $\begin{array}{c}\text { Yes } \\
0.458 \\
205 \\
\end{array}$ & $\begin{array}{c}\text { Yes } \\
0.461 \\
205 \\
\end{array}$ & $\begin{array}{c}\text { Yes } \\
0.456 \\
205 \\
\end{array}$ & $\begin{array}{c}\text { Yes } \\
0.470 \\
205 \\
\end{array}$ & $\begin{array}{c}\text { Yes } \\
0.467 \\
205 \\
\end{array}$ \\
\hline
\end{tabular}


(Table 4 continued)

\begin{tabular}{|c|c|c|c|c|c|c|c|}
\hline \multicolumn{8}{|c|}{ Panel B: OVERHANG3 (Stock option overhang for technical and business personnel) } \\
\hline Variable & $\begin{array}{c}\text { Expected } \\
\text { sign }(\text { OCA })\end{array}$ & $\begin{array}{c}\text { Expected } \\
\text { sign (MPA) }\end{array}$ & Model 1 & Model 2 & Model 3 & Model 4 & Model 5 \\
\hline Constant & & & $\begin{array}{c}0.098 * * * \\
(3.749)\end{array}$ & $\begin{array}{c}0.068 * * \\
(2.578) \\
\end{array}$ & $\begin{array}{c}0.095 * * * \\
(3.508)\end{array}$ & $\begin{array}{c}0.099 * * * \\
(3.784)\end{array}$ & $\begin{array}{c}0.070 * * \\
(2.557) \\
\end{array}$ \\
\hline EXECOWN & - & & $\begin{array}{c}-0.013 * * \\
(-2.274)\end{array}$ & $\begin{array}{c}-0.013 * * \\
(-2.246)\end{array}$ & $\begin{array}{c}-0.014 * * \\
(-2.255)\end{array}$ & $\begin{array}{c}-0.013^{* *} \\
(-2.290)\end{array}$ & $\begin{array}{c}-0.013 * * \\
(-2.230)\end{array}$ \\
\hline LSH & - & & $\begin{array}{l}-0.015^{*} \\
(-1.847)\end{array}$ & $\begin{array}{c}-0.017 * * \\
(-2.081)\end{array}$ & $\begin{array}{l}-0.014^{*} \\
(-1.807)\end{array}$ & $\begin{array}{l}-0.016^{*} \\
(-1.967)\end{array}$ & $\begin{array}{c}-0.018 * * \\
(-2.175)\end{array}$ \\
\hline INSTIT & - & & $\begin{array}{c}-0.001 \\
(-0.081)\end{array}$ & $\begin{array}{c}-0.002 \\
(-0.337)\end{array}$ & $\begin{array}{c}-0.001 \\
(-0.123)\end{array}$ & $\begin{array}{c}-0.001 \\
(-0.143)\end{array}$ & $\begin{array}{c}-0.003 \\
(-0.396)\end{array}$ \\
\hline FOREOWN & - & & $\begin{array}{c}-0.010 * * * \\
(-3.630)\end{array}$ & $\begin{array}{c}-0.010 * * * \\
(-3.402)\end{array}$ & $\begin{array}{c}-0.010 * * * \\
(-3.584)\end{array}$ & $\begin{array}{c}-0.011 * * * \\
(-3.648)\end{array}$ & $\begin{array}{c}-0.010 * * * \\
(-3.405)\end{array}$ \\
\hline STATEOWN & $?$ & - & $\begin{array}{c}-0.031 * * * \\
(-3.634)\end{array}$ & & $\begin{array}{c}-0.031 * * * \\
(-3.598)\end{array}$ & $\begin{array}{c}-0.033 * * * \\
(-3.717)\end{array}$ & \\
\hline SAMB & & $?$ & & $\begin{array}{c}-0.019 * * * \\
(-4.644)\end{array}$ & & & $\begin{array}{c}-0.019 * * * \\
(-4.615)\end{array}$ \\
\hline SOE & & $?$ & & $\begin{array}{c}0.002 \\
(0.326) \\
\end{array}$ & & & $\begin{array}{c}0.003 \\
(0.415) \\
\end{array}$ \\
\hline FSIZE & + & & $\begin{array}{c}-0.003 * * \\
(-2.377)\end{array}$ & $\begin{array}{c}-0.001 \\
(-1.000) \\
\end{array}$ & $\begin{array}{c}-0.003 * * \\
(-2.193)\end{array}$ & $\begin{array}{c}-0.003 * * \\
(-2.295) \\
\end{array}$ & $\begin{array}{c}-0.001 \\
(-0.924) \\
\end{array}$ \\
\hline CAPTOSAL & - & & $\begin{array}{c}-0.004 \\
(-0.946)\end{array}$ & $\begin{array}{c}-0.005 \\
(-1.107)\end{array}$ & $\begin{array}{c}-0.004 \\
(-0.915)\end{array}$ & $\begin{array}{c}-0.004 \\
(-0.951)\end{array}$ & $\begin{array}{c}-0.005 \\
(-1.120)\end{array}$ \\
\hline FOCUS & - & & $\begin{array}{c}-0.006 \\
(-0.761)\end{array}$ & $\begin{array}{c}-0.002 \\
(-0.291)\end{array}$ & & $\begin{array}{c}-0.007 \\
(-0.909)\end{array}$ & \\
\hline MATURE & $?$ & & & & $\begin{array}{c}-0.006 \\
(-0.759)\end{array}$ & & $\begin{array}{c}-0.003 \\
(-0.415)\end{array}$ \\
\hline GROWTH & $?$ & & & & $\begin{array}{c}-0.005 \\
(-0.610) \\
\end{array}$ & & $\begin{array}{c}-0.003 \\
(-0.416) \\
\end{array}$ \\
\hline BTOM & - & & $\begin{array}{c}0.010 \\
(1.355)\end{array}$ & $\begin{array}{c}0.005 \\
(0.836)\end{array}$ & $\begin{array}{c}0.010 \\
(1.339)\end{array}$ & $\begin{array}{c}0.010 \\
(1.357)\end{array}$ & $\begin{array}{c}0.005 \\
(0.818)\end{array}$ \\
\hline TOTRISK & $+/-$ & & $\begin{array}{c}0.001 \\
(1.136) \\
\end{array}$ & $\begin{array}{c}0.001 \\
(1.313) \\
\end{array}$ & $\begin{array}{c}0.001 \\
(1.146) \\
\end{array}$ & & \\
\hline SYSRISK & $?$ & & & & & $\begin{array}{c}-0.091 \\
(-1.323) \\
\end{array}$ & $\begin{array}{c}-0.075 \\
(-1.072) \\
\end{array}$ \\
\hline UNSYSRISK & $?$ & & & & & $\begin{array}{c}0.001 \\
(0.800)\end{array}$ & $\begin{array}{c}0.001 \\
(0.953)\end{array}$ \\
\hline DIVD & - & & $\begin{array}{c}-0.001 \\
(-0.410) \\
\end{array}$ & $\begin{array}{c}-0.002 \\
(-0.502) \\
\end{array}$ & $\begin{array}{c}-0.002 \\
(-0.468) \\
\end{array}$ & $\begin{array}{c}-0.001 \\
(-0.354) \\
\end{array}$ & $\begin{array}{c}-0.001 \\
(-0.440) \\
\end{array}$ \\
\hline LDEBTTOASS & - & & $\begin{array}{c}0.003 \\
(0.156)\end{array}$ & $\begin{array}{c}0.006 \\
(0.326)\end{array}$ & $\begin{array}{c}0.003 \\
(0.184)\end{array}$ & $\begin{array}{c}0.003 \\
(0.142)\end{array}$ & $\begin{array}{c}0.006 \\
(0.321)\end{array}$ \\
\hline PRETURN & + & & $\begin{array}{c}0.002 \\
(0.701) \\
\end{array}$ & $\begin{array}{c}0.002 \\
(0.683) \\
\end{array}$ & $\begin{array}{c}0.002 \\
(0.743) \\
\end{array}$ & $\begin{array}{c}0.002 \\
(0.628) \\
\end{array}$ & $\begin{array}{c}0.002 \\
(0.609) \\
\end{array}$ \\
\hline CFTOASS & + & & $\begin{array}{c}0.006 \\
(0.218)\end{array}$ & $\begin{array}{c}-0.006 \\
(-0.240)\end{array}$ & $\begin{array}{c}0.007 \\
(0.292)\end{array}$ & $\begin{array}{c}0.001 \\
(0.053)\end{array}$ & $\begin{array}{c}-0.010 \\
(-0.422)\end{array}$ \\
\hline PRPLAN & - & & $\begin{array}{c}0.003 \\
(0.534) \\
\end{array}$ & $\begin{array}{c}0.001 \\
(0.209) \\
\end{array}$ & $\begin{array}{c}0.003 \\
(0.534) \\
\end{array}$ & $\begin{array}{c}0.003 \\
(0.514) \\
\end{array}$ & $\begin{array}{c}0.001 \\
(0.203) \\
\end{array}$ \\
\hline BBPLAN & + & & $\begin{array}{c}0.004 \\
(1.124) \\
\end{array}$ & $\begin{array}{c}0.004 \\
(1.115) \\
\end{array}$ & $\begin{array}{c}0.004 \\
(1.158) \\
\end{array}$ & $\begin{array}{c}0.005 \\
(1.277) \\
\end{array}$ & $\begin{array}{c}0.005 \\
(1.240) \\
\end{array}$ \\
\hline $\begin{array}{l}\text { Year dummies } \\
\text { Adjusted } \mathrm{R}^{2} \\
\text { no. of obs. }\end{array}$ & & & $\begin{array}{c}\text { Yes } \\
0.098 \\
213\end{array}$ & $\begin{array}{c}\text { Yes } \\
0.144 \\
213\end{array}$ & $\begin{array}{c}\text { Yes } \\
0.094 \\
213\end{array}$ & $\begin{array}{c}\text { Yes } \\
0.098 \\
213\end{array}$ & $\begin{array}{c}\text { Yes } \\
0.139 \\
213\end{array}$ \\
\hline
\end{tabular}


(Table 4 continued)

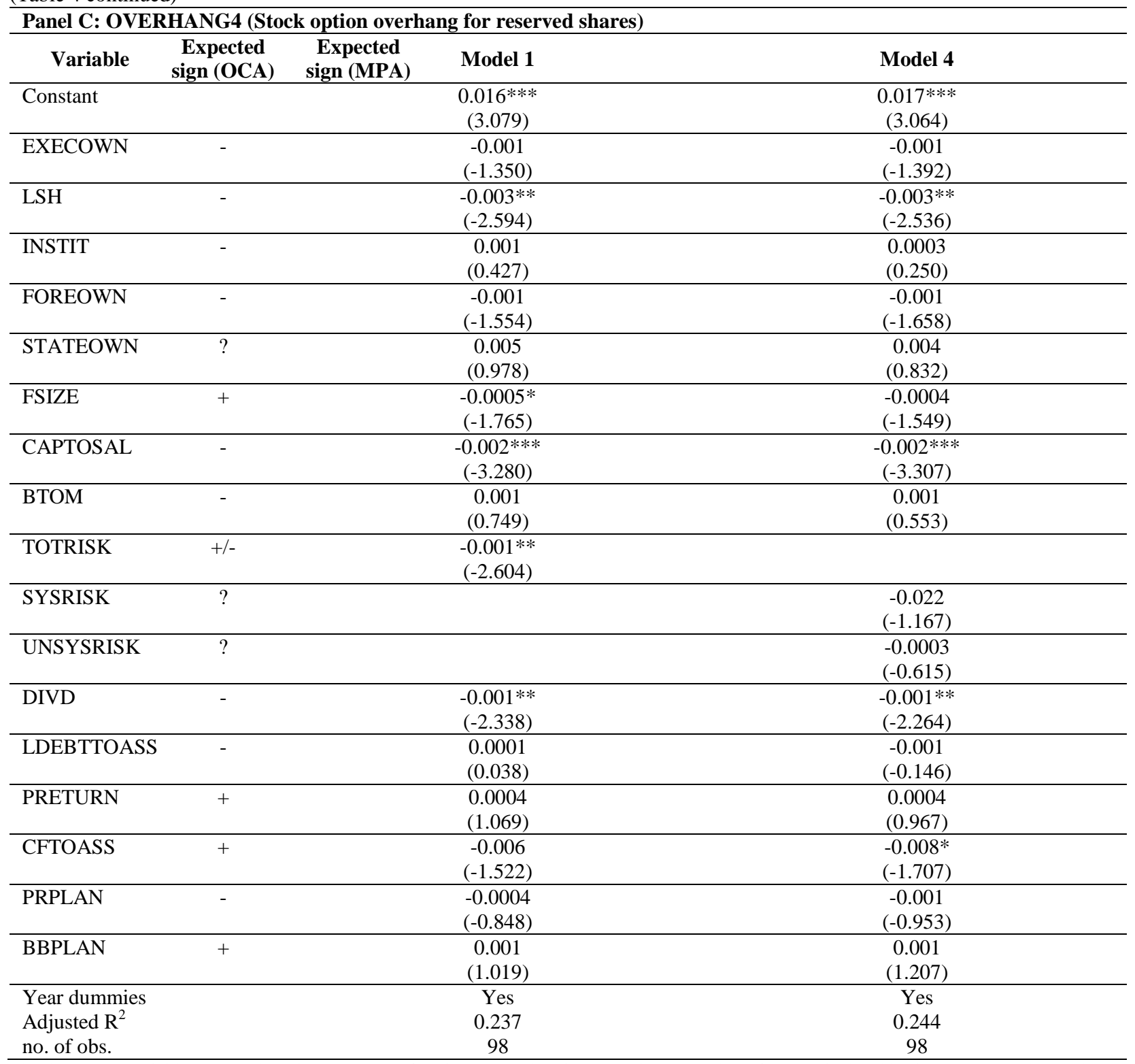

The dependent variables are stock option overhangs for directors and senior executives (Panel A), for technical and business personnel (Panel B), and for reserved shares (Panel C), respectively. All of the independent variables are lagged one year. Definitions of each variable are given in Appendix. All risk measures are multiplied by 100 for presentation in the table. Figures in parentheses are t-statistics. Year dummies are included in all regressions but not reported. * refers to significance at the 10 percent level; ** refers to significance at the 5 percent level; and $* * *$ refers to significance at the 1 percent level.

As for the senior management sample, although most of the coefficients on ownership variables have the expected signs, some (e.g. LSH and FOREOWN) are insignificant. Consistent with our earlier findings, STATEOWN and SAMB affect the stock option scope negatively and uniformly when they are targeted to senior executives, but surprisingly SOE is now statistically positive. A possible interpretation of the difference is that state ownership reflects mainly the political pressure on compensation curbs, while ultimate controlling shareholders' type reflects the rivalry between government intervention and managerial rent extraction. When firms are controlled by state agencies, political intervention tends to be stronger, whereas when firms are controlled by SOEs, managers tend to have more power and may require excessive compensation. An alternative explanation for the senior 
management model suggests that firms controlled by SOEs have higher pay-performance sensitivities than those controlled by state agencies and thus use more stock-related compensation.

The results of firm characteristics in Panel A reveal a similar picture as in Table 3. Firm size, firm focus, systematic risks and dividend dummy are negatively associated with equity grants to senior executives. Furthermore, book-to-market ratio and prior return are positively associated with equity grants to senior executives. In the senior executive model, while the coefficient for systematic risks remains significantly negative, the coefficient for total risks is no longer significant, suggesting managers are more concerned about systematic risks when making compensation decisions. The most pronounced difference from earlier findings is that leverage is statistically positive in the senior executive model. This contradicts the prediction that the disciplinary role of debt may reduce agency costs, and higher leverage would be associated with less need for equity incentives. However, our result is consistent with Alves (2011)'s finding and this can be explained with Choe (2003)'s theory that the number of stock options is increased to alleviate management underinvestment problem. Moreover, if high financial leverage indicates a shortage of cash, more stock options are used in place of cash compensation. Different from the pooled sample, the coefficient on the broad-based plan indicator for the senior executives sample indicates an opposite sign. The interpretation of the difference is simple. Normally, the scope is larger in plans that are targeted to a broader base of employees. On the other hand, if top management is the only group of recipients, the relative size tends to be larger, especially when Chinese regulation requires the option pool not exceed $10 \%$ of the outstanding shares.

Broadly speaking, previously observed correlations between total stock option overhang and ownership variables still hold for the core technician sample. The results in Panel B show that besides ownership structure, only firm size is significantly associated with the stock option overhang for technicians. Although coefficients on the remaining explanatory variables have the same signs as those for the pooled sample, they lose significance for the core technician sample.

In Panel $\mathrm{C}$ of Table 4, the dependent variable is stock option overhang for reserved shares. In this model, the independent variables are the same as before, but exclude FOCUS (as well as MATURE and GROWTH), SAMB and SOE, because the firms with reserved shares are all focus firms and only one firm has state ownership. As shown in Table 2, stock option overhang for reserved shares is much less than current awards. The mean ratio of reserved grants to total outstanding shares (total target shares) is $0.1 \%(4.2 \%)$, and the maximum is $0.1 \%(13.3 \%)$. Among the 104 firms granting reserved shares, the mean ratio of reserved grants to total target shares is $9.2 \%$, which is close to the $10 \%$ upper bound of normal standard.

Many of the variables do not seem to be related to OVERHANG4. The only significant ownership variable is LSH. Firm size and dividend dummy are also significantly negative. All these results are consistent with earlier findings. While the coefficients on prior stock returns are significantly positive for top management, they lose significance for middle level employees (most are core technicians) and reserved grants (most are for new employees). One possible explanation for these results is that senior managers are granted more options as a reward for past performance. Since past performance occurred before new employees hired, the insignificant relation is understandable.

The results for reserved shares differ from those for the other sample groups in some respects. First, capitalto-sales significantly affects the scope of stock options only in the reserved shares sample. In line with the OCA hypothesis, the negative relationship suggests that options are used more in more complex firms (a low ratio of capital-to-sales). Second, the total risk is positively associated with OVERHANG1, but negatively associated with OVERHANG4. A possible interpretation of the difference is that options reserved for new talents reflect mainly employees' risk aversion. As new hires are not familiar with the firm and their ability to impact share price is lower, they tend to receive less equity-based incentives especially in risky environment. Finally, cash flow-to-assets ratio is now significantly negative in Model 4. This contradicts the hypothesis that cash flow-to-assets ratio proxies profitability, and higher profitability would be associated with more option grants if stock options are used to reward past performance. If cash flow-to-assets ratio instead proxies for liquidity constraints, less stock options are needed to replace cash compensation for cash sufficient companies. 


\section{CONCLUSION}

This paper examines the economic determinants of ESO plans in Chinese firms from the optimal contract and managerial power approaches. Using a sample of 225 observations over the period January 2006 to June 2013, we investigate the determinants of the size (i.e. the ratio of granted options to outstanding shares) as well as the value (i.e. the ratio of Black-Scholes value of option awards to market value of equity) of stock option plans. In addition, we examine the relative importance of different factors of stock option plans to directors and senior executives, technical and business personnel, and special talents introduced in the future.

There are some important findings particular to Chinese market. At the stock market level, we find that stock option schemes become more popular during a stock market downturn. It suggests that managers intentionally choose the right time to set a lower exercise price to earn potential benefits from the option. Findings from firmlevel analysis often corroborate previous results in the literature, but important differences also emerge. We find that the scope of stock option plans is negatively associated with firm size, dividend dummy, and three ownership measures (EXECOWN, LSH, and FOREOWN). These results are consistent with the OCA, in that greater public scrutiny, sufficient cash, and stronger ownership control reduce the need for stock option grants. Furthermore, we find that the scope of stock option plans is positively related to book-to-market ratio and prior stock returns, but the coefficients are significant only when the stock options granted cover senior managers. Since middle level employees have less ability than senior executives to impact stock price, this provides an additional support for using options as a reward for past performance. In literature, the relation between the scope of stock option plans and firm risk is ambiguous as risk may proxy both monitoring difficulty as well as the extent to which risk-averse managers can be incentivized. We find that the impact of risk is different when options are targeted to different types of employees. Our findings imply that systematic risks mainly reflect managerial risk aversion and they have a much larger effect on stock option usage. These findings may help reconciling the conflicting empirical results on the effects of risk on stock options in past studies. In other cases, our findings reveal the special institutional settings in China. We find that the scope of stock option plans is inversely related to state ownership. This is consistent with the MPA, suggesting political pressure may constrain stock option compensation in state-owned firms. Such constraint is not only for senior managers but also for middle level employees. The degree of impact from the other economic factors is different across a broad base of employees. In general, ownership variables are more relevant to key technical and business personnel, while firm characteristics variables are more relevant to top management.

This paper contributes to existing literature by providing additional evidence on the determinants of stock option grants to both executives and non-executive employees, in the context of Chinese emerging market. We provide a comprehensive description of a large sample of Chinese stock option plans. Moreover, we investigate whether the differences in the structure of option grants are related to different types of grantees.

Our results carry important implications for investors in understanding the incentive compensation system to motivate different types of employees. Moreover, our results have implications for regulators in establishing a healthier equity incentive system in China.

\section{AUTHOR INFORMATION}

Dr. Lei Luo is an assistant professor of accounting in the School of Management at Xi'an Jiaotong University. Her main research interests include corporate governance and firm performance. E-mail: luolei@ mail.xjtu.edu.cn

\section{REFERENCES}

Alves, S. (2011). The economic determinants of executive stock options grants in Portuguese firms. Journal of Accounting, Business \& Management, 18(1), 19-38.

Baker, G.P. and Hall, B.J. (2004). CEO incentives and firm size. Journal of Labor Economics, 22, 767-798.

Bryan, S., Hwang, L., and Lilien, S. (2000). CEO stock-based compensation: an empirical analysis of incentiveintensity, relative mix and economic determinants. Journal of Business, 73, 661-693.

Cao, J., Pan, X., and Tian, G. (2011). Disproportional ownership structure and pay-performance relationship: evidence from China's listed firms. Journal of Corporate Finance, 17 (3), 541-554. 
Chen, G., Firth, M., and Xu, L. (2009). Does the type of ownership control matter? Evidence from China's listed companies. Journal of Banking \& Finance, 33, 171-181.

Choe, C. (2003). Leverage, volatility and executive stock options. Journal of Corporate Finance, 9, 591-609.

Chourou, L., Abaoub, E., and Saadi, S. (2008). The economic determinants of CEO stock option compensation. Journal of Multinational Financial Management, 18(1), 61-77.

Core, J. and Guay, W. (1999). The use of equity grants to manage optimal equity incentive levels. Journal of Accounting and Economics, 28, 151-184.

Core, J. and Guay, W. (2001). Stock option plans for non-executive employees. Journal of financial economics, 61, 253-287.

Demsetz, H. and Lehn, K. (1985).The structure of corporate ownership: causes and consequences. Journal of Political Economy, 93, 1155-1177.

Firth, M., Fung, P., and Rui, O.M. (2006). Corporate performance and CEO compensation in China. Journal of Corporate Finance, 12, 693-714.

Gaver, J. and Gaver, K. (1993). Additional evidence on the association between the investment opportunity set and corporate financing, dividend, and compensation policies. Journal of Accounting and Economics, 16, 125160.

Gaver, J. and Gaver, K. (1995). Compensation policy and the investment opportunity set. Financial Management, 24, 19-32.

Ittner, C.D., Lambert, R.A., and Larcker, D.F. (2003). The structure and performance consequences of equity grants to employees of new economy firms. Journal of Accounting and Economics, 34, 89-127.

Jensen, M.C. (1993).The modern industrial revolution, exit, and the failure of internal control systems. Journal of Finance, 48, 831-880.

Jensen, M.C. and Meckling, W.H. (1976). Theory of the firm: managerial behavior, agency costs and ownership structure. Journal of Financial Economics, 3, 305-360.

John, K. and John, T. (1993). Top-management compensation and capital structure. Journal of Finance, 48, 949974.

Kato, H.K., Lemmon, M., Luo, M., and Schallheim, J. (2005). An empirical examination of the costs and benefits of executive stock options: evidence from Japan. Journal of Financial Economics, 78 (2), 435-467.

Li, Y. and Liu, T. (2010). Study of effect factors of equity incentives. Journal of Shaanxi University of Science \& Technology, 28 (1), 153-158. (in Chinese)

Li, L. and Sanséau, P.Y. (2013). Influential factors of executives' equity-based revenue in Chinese-listed Companies. Journal of Applied Business Research, 29 (2), 379-390.

Liljeblom, E., Pasternack, D., and Rosenberg, M. (2011). What determines stock option contract design? Journal of Financial Economics, 102, 293-316.

Lv, C., Yan, M., Zheng, H., and Xu. J. (2011). Why corporates choose stock option? Evidence from China. Accounting Research, 2011 (1), 68-75. (in Chinese)

Mehran, H. (1995). Executive compensation structure, ownership and firm performance. Journal of Financial Economics, 38, 163-184.

Nagaoka, S. (2005). Determinants of the introduction of stock options by Japanese firms: analysis from the incentive and selection perspectives. Journal of Business, 78, 2289-2315.

Oyer, P. and Schaefer, S. (2005). Why do some firms give stock options to all employees? An empirical examination of alternative theories. Journal of Financial Economics, 76, 99-133.

Ryan, H.E.J. and Wiggins, R.A. (2001). The influence of firm- and manager-specific characteristics on the structure of executive compensation. Journal of Corporate Finance, 7, 101-123.

Uchida, K. (2006). Determinants of stock option use by Japanese companies. Review of Financial Economics, 15, 51-269.

Yermack, D. (1995). Do corporations award CEO stock options effectively? Journal of Financial Economics, 39, 237-269.

Yu, W. (2011). The relationship between internal governance, external environment and equity-based incentives. Statistics and Decision, 326, 151-153. (in Chinese) 


\section{NOTES}

${ }^{1}$ State-owned Assets Supervision and Administration Commission of the State Council promulgated the Trial Measures for the Implementation of Equity Incentive Plans by State Holding Listed Companies on September 30, 2006.

${ }^{2}$ Senior executives refer to the personnel who implement leading duties and responsibilities for the decision-making, operation and management of a company, including CEO, vice presidents, CFO, board secretary and other personnel as prescribed in the articles of association of the company.

${ }^{3}$ ST stands for Special Treatment. ST firms are listed firms that have suffered losses for two consecutive years.

${ }^{4}$ According to "Listing Corporation Industry Classification guide (2001)", firms are classified into 11 industries (i.e., Agricultural, forest, animal husbandry and fishery; Mining; Manufacturing; Electricity gas and water; Construction; Information technology; Wholesale and retail; Real estate; Social service; Communication and culture; and Industrial conglomerates). The classification criteria are as follows: (1) If at least 50\% of the firm's operating revenue are generated from one specific industry segment, the firm is classified as in the industry of this specific segment; (2) if none of any specific industry segment generates more than $50 \%$ of the total revenue but the revenue from the largest business segment is $130 \%$ larger than the second largest segment, the firm is classified as in the industry of the largest business segment. Otherwise, the firm is classified as in the industrial conglomerates industry. 


\section{APPENDIX}

Definition of variables

Dependent Variable

OVERHANG1 Total stock option overhang. The number of total target shares involved in the option plan to the number of outstanding shares at grant date

OVERHANG2 Stock option overhang for directors and senior executives. The number of shares granted to directors and senior executives divided by the number of outstanding shares at grant date

OVERHANG3 Stock option overhang for technical and business personnel. The number of shares granted to technical and business personnel divided by the number of outstanding shares at grant date

OVERHANG4 Stock option overhang for reserved shares. The number of reserved shares in the option plan to the number of outstanding shares at grant date

BSMV Total Black-Scholes value of option plan to market value of equity. We use the Black Scholes (1973) model to estimate stock option values. The total value of stock options is their Black-Scholes value multiplied by the total number of shares involved in the stock option plan. BSMV is the total BlackScholes value divided by the market value of equity

PREMIUM Stock option premium. Calculated as $[(\mathrm{X}-\mathrm{S}) / \mathrm{S}]$, where $\mathrm{X}$ is the exercise price of the option, and $\mathrm{S}$ is the stock price at the grant date

\begin{tabular}{|c|c|}
\hline Independent Variable & \\
\hline EXECOWN & Managerial ownership. The percentage of shares held by senior executives \\
\hline LSH & $\begin{array}{l}\text { Non-state ownership control. The percentage of shares owned by the largest private (i.e., non-state) } \\
\text { shareholder }\end{array}$ \\
\hline INSTIT & Institutional ownership. The percentage of shares held by institutions \\
\hline FOREOWN & $\begin{array}{l}\text { Foreign ownership. Dummy variable equal to } 1 \text { if a foreign investor is among the } 10 \text { largest } \\
\text { shareholders, } 0 \text { otherwise }\end{array}$ \\
\hline STATEOWN & State ownership. The percentage of shares held by the state \\
\hline SAMB & $\begin{array}{l}\text { SAMBs-controlled firms. Dummy variable equal to } 1 \text { if the company's actual controller is state assets } \\
\text { management bureaus, } 0 \text { otherwise }\end{array}$ \\
\hline SOE & $\begin{array}{l}\text { SOEs-controlled firms. Dummy variable equal to } 1 \text { if the company's actual controller is state owned } \\
\text { enterprises, } 0 \text { otherwise }\end{array}$ \\
\hline FSIZE & Firm size. The logarithm of the book value of assets \\
\hline CAPTOSAL & $\begin{array}{l}\text { Capital-to-sales. The ratio of fixed assets (book value of gross plant, property, and equipment) to sales, } \\
\text { as an inverse measure of monitoring difficulties }\end{array}$ \\
\hline FOCUS & $\begin{array}{l}\text { Firm focus. Firm focus is a dummy variable. It equals to } 0 \text { if the firm belongs to the industrial } \\
\text { conglomerates industry. It equals to } 1 \text { if the firms belongs to other industries }\end{array}$ \\
\hline MATURE & $\begin{array}{l}\text { Mature. Firm focus is further decomposed into mature and growth industries. The classification is } \\
\text { based on 2-digit industrial classification code from "Listing Corporation Industry Classification Guide } \\
\text { (2001)". Mature is a dummy variable, equal to } 1 \text { if the firm belongs to mature industry, } 0 \text { otherwise }\end{array}$ \\
\hline GROWTH & $\begin{array}{l}\text { Growth. Firm focus is further decomposed into mature and growth industries. The classification is } \\
\text { based on 2-digit industrial classification code from "Listing Corporation Industry Classification Guide } \\
\text { (2001)". Growth is a dummy variable, equal to } 1 \text { if the firm belongs to growth industry, } 0 \text { otherwise }\end{array}$ \\
\hline BTOM & $\begin{array}{l}\text { Book-to-market ratio. The book value of asset to firm's market value, as an inverse measure of } \\
\text { investment opportunities }\end{array}$ \\
\hline TOTRISK & $\begin{array}{l}\text { Total risk. The variance of daily stock total returns during the firm's accounting period, using a } \\
\text { minimum of } 60 \text { daily stock returns as inclusion criteria }\end{array}$ \\
\hline SYSRISK & $\begin{array}{l}\text { Systematic risk. Estimated by a year-to-year market model regression based on daily stock returns, and } \\
\text { calculated as the squared beta multiplied by the variance of daily market index returns. We use A } \\
\text { Share Composite Index (including Growth Enterprises Market) as the market index }\end{array}$ \\
\hline UNSYSRISK & $\begin{array}{l}\text { Unsystematic risk. Estimated by a year-to-year market model regression based on daily stock returns, } \\
\text { and calculated as the residual variance from the market model. We use A Share Composite Index } \\
\text { (including Growth Enterprises Market) as the market index }\end{array}$ \\
\hline DIVD & Dividend dummy. Dummy variable equal to 1 if a firm pays dividends during the year, 0 otherwise \\
\hline LDEBTTOASS & Long-term debt-to-assets. The book value of long-term debt divided by the book value of assets \\
\hline PRETURN & $\begin{array}{l}\text { Prior stock return. The one year logarithmic stock return prior to the start of the fiscal year with the } \\
\text { stock option grant }\end{array}$ \\
\hline CFTOASS & Cash flow-to-assets ratio. The ratio of EBITDA to the book value of assets \\
\hline PRPLAN & Prior plan in effect. Dummy variable equal to 1 if a firm granted stock options before, 0 otherwise \\
\hline BBPLAN & $\begin{array}{l}\text { Broad-based plan. Dummy variable equal to } 1 \text { if stock options are granted to both senior executives } \\
\text { and technical and business personnel, } 0 \text { otherwise }\end{array}$ \\
\hline
\end{tabular}


NOTES 